\title{
Former Students’ Feedback On A Liberal Arts Undergraduate Course In Entrepreneurship
}

Karl A. Egge, (Email: egge@macalester.edu), Macalester College

\begin{abstract}
We present initial and preliminary results from a questionnaire survey in early 2005 of former students who took the only entrepreneurship class taught once/year at Macalester College. The objective was to elicit their opinions of what should be taught, the importance of alternative classroom pedagogies, and judgments on how to evaluate student performance. Highest encouragement was given to having outside guest entrepreneur speakers. They were not enthusiastic about the importance of journal articles or even textbooks. They would counsel entrepreneurial students facing constraints on what other courses they might consider, to take especially accounting/finance. They believe grades should be based more so on projects and participation than on performance on exams. They would emphasize the course's focus to be more on starting than growing a firm.
\end{abstract}

\section{INTRODUCTION}

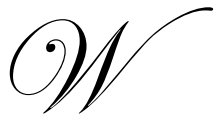

hat should be covered in an introductory course in entrepreneurship? How should students be evaluated? What teaching/learning strategies or pedagogy should be employed? These are some of the questions that motivated this questionnaire survey of former students, who had taken the author's course taught nearly every year for 20 years. The goal would be to assist new teachers, but also as an aide in a re-design of the existing course.

When the author began teaching this course there were few schools teaching entrepreneurship, and even fewer sources of advice to these questions. Today over 1,800 colleges, universities, and community colleges (Timmons, 2004, p. xi) offer if not one course a complete program in the topic. Indeed, there now are 563 endowed professorships in the discipline around the world (Katts, 2004).

The Kauffman Fund is a leader in pushing campuses to develop courses and encourage students to learn more about entrepreneurship. Yet, if a select liberal arts undergraduate college were only able to offer one course, what would it cover and how would it be taught? Keep in mind a full menu of entrepreneurial courses offered by those universities with a program or major includes dedicated courses in such topics as new ventures, large firm entrepreneurship, entrepreneurial finance, opportunity recognition, family business, franchising, women/minority, start ups, and LBO/private equity,

The preface and forward to textbooks help the new teacher evaluate and assess what topics to cover, and how to teach the course. There are programs for training entrepreneurship teachers (e.g., Price-Babson Fellows Program Symposium for Entrepreneurship Educators) that also are useful. Another approach would be to solicit the counsel of experts or judges on what to teach and how to teach the topic. The objective of this paper is to report the results from one category of such judges - former students. From the perspective of a liberal arts college the expectation that many graduates of an entrepreneurship class will have launched a business is very low. However, many of us who are not practicing entrepreneurs can learn from the pedagogical tools and topics covered in such a course. 


\section{SAMPLE SURVEYED}

\section{A Liberal Arts College perspective}

The Appendix Table summarizes some of the data about Macalester College. This is the US, highly academic selective, private, 4-year undergraduate college the sample attended. Macalester has no business department. It has offered 1 course per year in entrepreneurship for 20 years taught by an economist with a finance background. That course's focus was on starting new ventures, but as taught by the author it tried also to briefly touch on some of the areas where at other schools an entire course might be offered (e.g., franchising). Students took the entrepreneurship class as an elective within the economics department.

\section{The Sample}

Table I summarizes the population (331 former students from 18 former classes taught by the author) from which the sample (67 at the time this paper was prepared) was drawn.

\begin{tabular}{|c|c|}
\hline \multicolumn{2}{|c|}{$\begin{array}{l}\text { Table I: Entrepreneurship Classes at Macalester College } \\
\qquad 1984-2004\end{array}$} \\
\hline \multirow{2}{*}{$\begin{array}{l}\text { Number of entrepreneurship classes Dr. E. taught these years } \\
\text { Number of grades given by Dr. E. in those courses }\end{array}$} & 18 \\
\hline & 331 \\
\hline \multicolumn{2}{|l|}{ Number of email addresses available for former students } \\
\hline \multirow{3}{*}{$\begin{array}{l}\text { from those classes } \\
* \text { Number of email/questionnaires rejected } \\
* \text { Number of respondents }\end{array}$} & 201 \\
\hline & 16 \\
\hline & 67 \\
\hline Number of respondents (as of $4 / 25 / 05$ ) & 67 \\
\hline \multirow{3}{*}{$\begin{array}{l}\text { Number of female students } \\
\text { \# of Respondents from classes taught in 1984-1994 } \\
\text { \# of Respondents from classes taught in 1995-2004 }\end{array}$} & 14 \\
\hline & 27 \\
\hline & 40 \\
\hline
\end{tabular}

Table II provides details on the former students. Some of the highlights include $37 \%$ were international students when they attended Macalester, 35\% now earn the equivalent of more than $\$ 94,000 / \mathrm{yr}$ US, $54 \%$ went on to graduate school, $17 \%$ work in the nonprofit sector (e.g., public school teacher).

Among the traits one might expect to find among former students who took an entrepreneurship class, $29 \%$ claimed they (alone or with others) started at least 1 business. Including those who simply work for a start up business they represent $37 \%$ of the respondents. Also indicative of their "entrepreneurial experience" and expertise, $60 \%$ report they worked for a firm that went through a major expansion, $29 \%$ with experience at a firm that went through a major contraction, and $10 \%$ worked for firms that went bankrupt. It is good to see that $92 \%$ report they are happy with their careers!

\section{RESULTS}

\section{Opinions on Teaching}

Table III contains most of their opinions. For ease of interpretation those who chose strongly agree and those who chose agree are added together to obtain the percentage who "agree" with a statement. However, it is worth keeping in mind that the intensity (or lack thereof) of their opinions is clouded with this procedure. 


\begin{tabular}{|c|c|c|c|c|c|}
\hline \multicolumn{6}{|c|}{$\begin{array}{c}\text { Table II: Background on Responding Former } \\
\text { Students of an Entrepreneurship Class } \\
\text { Taken Between } 1984 \text { and } 2004\end{array}$} \\
\hline \multicolumn{2}{|c|}{ Total Responses: } & 67 & $\begin{array}{c}\text { \% Yes or } \\
\text { Agreeing }\end{array}$ & $\begin{array}{c}\% \text { No or } \\
\text { Disagreeing }\end{array}$ & \% N.A. \\
\hline \multirow{3}{*}{\multicolumn{3}{|c|}{$\begin{array}{l}\text { I started at least one business. } \\
\text { I worked for what I consider a start up } \\
\text { business. } \\
\text { I have a graduate degree, or am currently } \\
\text { working on one. }\end{array}$}} & $29.3 \%$ & $69.2 \%$ & $1.5 \%$ \\
\hline & & & $37.0 \%$ & $61.5 \%$ & $1.5 \%$ \\
\hline & & & $53.8 \%$ & $46.2 \%$ & $0.0 \%$ \\
\hline \multicolumn{3}{|c|}{ I was an international student at Macalester } & $37.0 \%$ & $63.1 \%$ & $0.0 \%$ \\
\hline & & a. Went bankrupt. & $10.8 \%$ & $86.2 \%$ & $3.1 \%$ \\
\hline \multirow{2}{*}{\multicolumn{2}{|c|}{$\begin{array}{l}\text { I have worked for a } \\
\text { business that: }\end{array}$}} & $\begin{array}{l}\text { b. Went through } \\
\text { major expansion. }\end{array}$ & $60.2 \%$ & $38.6 \%$ & $1.3 \%$ \\
\hline & & $\begin{array}{l}\text { c. Went through } \\
\text { major contraction. }\end{array}$ & $29.2 \%$ & $67.7 \%$ & $3.1 \%$ \\
\hline \multirow{3}{*}{ I am now: } & $\begin{array}{l}\text { a. Self } \\
\text { (signif }\end{array}$ & $\begin{array}{l}\text { mployed, or owner } \\
\text { ant \%). }\end{array}$ & $18.6 \%$ & $67.7 \%$ & $13.7 \%$ \\
\hline & b. Offi & ar/mgr. of a firm. & $33.7 \%$ & $47.8 \%$ & $18.5 \%$ \\
\hline & c. Neit & er (a) nor (b). & $52.3 \%$ & $30.8 \%$ & $16.9 \%$ \\
\hline \multirow{3}{*}{\multicolumn{3}{|c|}{$\begin{array}{l}\text { I am happy with my career path. } \\
\text { I work for a non-profit organization. } \\
\text { My earnings (or equivalent) are running above } \\
\text { a professor's } \$ 94,000 / \text { yr gross }\end{array}$}} & $92.5 \%$ & $6.0 \%$ & $1.5 \%$ \\
\hline & & & $16.9 \%$ & $83.1 \%$ & $0.0 \%$ \\
\hline & & & $34.9 \%$ & $60.5 \%$ & $4.6 \%$ \\
\hline
\end{tabular}

\section{Textbook Vs. Articles Vs. Guests Vs. Cases Vs. Project?}

Standing out in Table III with the most intense opinion is their affirmation of the importance of guest speakers - 100\% agreeing, of whom 90\% saying strongly agree. In written comments at the bottom of their questionnaires they indicated that they could read the text book on their own and did not need it covered in the classroom. What they liked about having entrepreneurial guest speakers was the breadth of exposure they got to business, new ventures, problems and pitfalls, advice comments from them, and so forth.

A close second most important teaching method based on their opinions was doing case studies of entrepreneurs. Most entrepreneurship textbooks have cases, and some of these former students responded that going over and discussing the cases was very helpful. In written comments several reported that detailed (lengthy) cases were preferred to abbreviated summary cases embedded in a chapter of a text. Almost at the same affirmative level in their opinion was having a research project in which they worked with at least 1 other student (i.e., as a team).

The importance of an entrepreneurship textbook or entrepreneurship journal articles, while valued, was rated much lower in comparison to the use of guests and cases by this group of judges. Factor analysis revealed (i.e., load $\# 1$ - but only $3 \%$ of the variance) those who did advocate textbooks and articles, also encouraged students to take math, and weighted highly teaching emphasis on operations and management. 


\begin{tabular}{|c|c|c|c|c|c|}
\hline \multicolumn{6}{|c|}{$\begin{array}{c}\text { Table III: Opinions on Teaching Entrepreneurship by Responding Former } \\
\text { Students of an Entrepreneurship Class } \\
\text { Taken Between } 1984 \text { and } 2004 \\
\end{array}$} \\
\hline & \begin{tabular}{|l} 
Strongly \\
Agree \\
or Yes
\end{tabular} & $\begin{array}{c}\begin{array}{c}\text { Agree } \\
\text { or } \\
\text { Yes }\end{array} \\
\end{array}$ & \begin{tabular}{c|} 
\% who \\
Agree \\
or Yes $*$
\end{tabular} & $\begin{array}{l}\text { Disagree } \\
\text { or } \\
\text { No }\end{array}$ & $\begin{array}{c}\text { Strongly } \\
\text { Disagree } \\
\text { or No }\end{array}$ \\
\hline $\begin{array}{l}\text { A textbook on entrepreneurship is important. } \\
\text { Reading academic journal articles on ent. is important. } \\
\text { Having outside guest entrepreneur speakers is important. } \\
\text { Having a student research project is important. } \\
\text { Work with at least } 1 \text { other student on a project is important } \\
\text { Doing case studies in class is important. } \\
\text { Major emphasis should be given to: } \\
\text { a. Entrepreneurial finance. } \\
\text { b. Operations/management/marketing. } \\
\text { c. "Opportunity" analysis. } \\
\text { Ent. should not be taught to liberal arts undergraduates. } \\
\text { Someone who takes an ent. class should also take lots of: } \\
\text { a. Math \& computer science classes } \\
\text { b. Psychology, sociology, geography classes } \\
\text { c. Accounting \& finance classes } \\
\text { Relatively higher portion of the grade should be based on: } \\
\text { a. Class participation. } \\
\text { b. Exam performance. } \\
\text { c. Project } \\
\text { Relatively more emphasis should be given to: } \\
\text { a. Starting a new firm. } \\
\text { b. Growing an existing firm. } \\
\text { c. Topics in Private Equity/LBOs/Spin-outs. } \\
\text { d. Venture Capital. }\end{array}$ & $\begin{array}{c}31 \\
27 \\
38 \\
3 \\
\\
4 \\
11 \\
34\end{array}$ & $\begin{array}{c}34 \\
35 \\
25 \\
1 \\
\\
\\
32 \\
29 \\
28\end{array}$ & $\begin{array}{c}97.0 \% \\
96.9 \% \\
95.5 \% \\
6.1 \% \\
\\
54.5 \% \\
60.6 \% \\
93.9 \%\end{array}$ & $\begin{array}{c}2 \\
2 \\
2 \\
8 \\
\\
26 \\
23 \\
3\end{array}$ & $\begin{array}{l}5 \\
1 \\
0 \\
0 \\
0 \\
0\end{array}$ \\
\hline $\begin{array}{l}\text { * percentage is those with an opinion who selected agree } \\
\text { * factor analysis of results loaded 1st (3\% of variance) on } \\
\text { as accounting/finance, and focus on growing an existing f } \\
\text { answers to importance of textbook and journal articles, ta } \\
\text { on operations and management. }\end{array}$ & math, & $\begin{array}{l}\text { ee } \\
\text { ojec } \\
2.59 \\
\text { mo }\end{array}$ & $\begin{array}{l}\text { ke math c } \\
\text { as on } \\
\text { me spent }\end{array}$ & as well & \\
\hline
\end{tabular}

\section{Counsel On What Other Courses To Take?}

Table III reveals their first choice would be additional courses in accounting and finance. It was surprising to see additional courses in math and/or computer science coming in $3^{\text {rd }}$ of the 3 sets of courses, because at Macalester that is the most likely double major combination with economics.

\section{Focus Of The Course?}

They voted for new venture start up as the most important, followed by venture capital. Surprisingly about $1 / 3$ disagreed with emphasizing the importance of growing an existing firm and/or such topics as spin outs and private equity.

\section{Grading?}

There was near unanimity for placing a higher percentage of one's grade on their project, and a lower percentage of one's grade on exam performance. When these students took the entrepreneur class taught by the author typically $75 \%$ of the grade was based on exam performance. 


\section{Pedagogy?}

Table IV shows how they ranked the alternative teaching-learning methods. Clearly highest rated was the use of guest speakers with $71 \%$ rating this as their $\# 1$ or \#2 choice. Almost shockingly low rated were textbook (4\% selected it as \#1 or \#2) and journal articles (only 3\%). Student projects and cases both were approximately \#1 or \#2 with at least $1 \frac{1}{2}$ the respondents.

\begin{tabular}{|l|c|c|c|c|}
\hline \multicolumn{5}{|c|}{$\begin{array}{c}\text { Table IV: Importance of Alternative Teaching Aides or Pedagogy } \\
\text { For an Entrepreneurship Class by Responding } \\
\text { Former Students From 1984-2004 }\end{array}$} \\
\cline { 2 - 4 } & \multicolumn{3}{|c|}{ \# of respondents who rated this } & Rated \\
\hline \hline & $\# 1$ & $\# 2$ & $\# 3$ & This in \\
& & & & Top 2 \\
\hline Textbook in Entrepreneurship & 3 & 0 & 4 & $4.6 \%$ \\
Journal Articles about Ent. & 1 & 1 & 3 & $3.1 \%$ \\
Guest Entrepreneur Speakers & 33 & 13 & 10 & $70.8 \%$ \\
Student Projects for Class & 12 & 23 & 22 & $53.8 \%$ \\
Working with other students & 4 & 11 & 10 & $23.1 \%$ \\
Doing Case Studies & 13 & 18 & 17 & $47.7 \%$ \\
NA & 1 & 1 & 1 & $3.1 \%$ \\
\hline \hline total & 67 & 67 & 67 & \\
\hline
\end{tabular}

\section{Differences By Characteristics Of The Respondents}

Table $\mathrm{V}$ presents one way of assessing how the respondents might differ in their recommendations depending on their experiences. Assigning a 1 to strongly agree through a 4 to strongly disagree the mean value for each recommendation is compared one group to another. No attempt is made at this time to statistically assess whether a mean from one group is statistically different from the mean of another. Rather, the objective is to see if any apparent differences exist, such as by .3 percentage points or more.

The first group of former students is those who work with nonprofit firms. The second is those reporting their earnings exceed $\$ 94,000 / y r$. There is no overlap between the members of these two groups. As one looks at the differences between their answers or opinions, the noteworthy conclusion is how similar they are. The only .3-point differences are in whether more emphasis should be given to private equity/LBO/spin outs (the higher income people say more emphasis), and in whether current students should take more courses in psychology/geography/sociology (again the higher income people agreeing more strongly). Both groups' first choice for teaching aides is use of guest speakers.

While it is a small group, the 7 who worked for a firm that went through a bankruptcy were somewhat more likely than other groups to be opposed to exams, and in favor of taking more math. 


\begin{tabular}{|c|c|c|c|c|c|c|}
\hline \multicolumn{7}{|c|}{$\begin{array}{c}\text { Table V: In Search of Different Opinions About Teaching Among } \\
\text { Former Students of an Entrepreneurship Class } \\
\text { Taken Between } 1984 \text { and } 2004 \\
\end{array}$} \\
\hline \multirow[t]{3}{*}{ Means of Rankings } & \multirow{3}{*}{$\begin{array}{l}\text { If } 1=\text { Strongly Agree } \\
2=\text { Agree } \\
3=\text { Disagree } \\
4=\text { Strongly Disagree }\end{array}$} & \multirow{3}{*}{\begin{tabular}{|c|}
11 In \\
Nonprofit \\
Firms \\
\\
Mean \\
\end{tabular}} & \multirow{3}{*}{$\begin{array}{c}23 \text { Earn } \\
\text { over } \\
\$ 94 \mathrm{~K} \\
\\
\text { Mean } \\
\end{array}$} & \multirow{3}{*}{$\begin{array}{c}7 \text { with } \\
\text { Bankruptcy } \\
\text { Experience } \\
\text { Mean } \\
\end{array}$} & \multirow{3}{*}{$\begin{array}{l}40 \text { went } \\
\text { through } \\
\text { major } \\
\text { expansion } \\
\text { Mean }\end{array}$} & \multirow{3}{*}{$\begin{array}{c}33 \text { longes } \\
\text { out of } \\
\text { college } \\
\text { Mean } \\
\end{array}$} \\
\hline & & & & & & \\
\hline & & & & & & \\
\hline \multirow{7}{*}{\multicolumn{2}{|c|}{$\begin{array}{l}\text { A textbook on entrepreneurship is important. } \\
\text { Reading journal articles on ent. is important. } \\
\text { Having guest entrepreneur speakers is important. } \\
\text { Having a student research project is important. } \\
\text { Work with at least } 1 \text { other student on a project } \\
\text { Doing case studies in class is important. } \\
\text { Major emphasis should be given to: }\end{array}$}} & 2.1 & 2.0 & 2.3 & 2.2 & 2.1 \\
\hline & & 1.7 & 2.0 & 2.0 & 2.1 & 1.9 \\
\hline & & 1.2 & 1.0 & 1.0 & 1.1 & 1.1 \\
\hline & & 1.2 & 1.2 & 1.1 & 1.2 & 1.3 \\
\hline & & 1.2 & 1.4 & 1.1 & 1.3 & 1.5 \\
\hline & & 1.3 & 1.1 & 1.3 & 1.1 & 1.1 \\
\hline & & & & & & \\
\hline \multicolumn{2}{|c|}{ a. Entrepreneurial finance. } & 1.6 & 1.4 & 1.7 & 1.6 & 1.5 \\
\hline \multicolumn{2}{|c|}{ b. Operations/mgt./mktg. } & 1.4 & 1.6 & 1.6 & 1.6 & 1.6 \\
\hline \multicolumn{2}{|c|}{ c. "Opportunity" analysis. } & 1.6 & 1.5 & 1.6 & 1.5 & 1.4 \\
\hline \multirow{2}{*}{\multicolumn{2}{|c|}{$\begin{array}{l}\text { Ent. should not be taught to undergraduates. } \\
\text { Someone who takes an ent. class also take: }\end{array}$}} & 3.8 & 3.7 & 3.9 & 3.6 & 3.6 \\
\hline & & & & & & \\
\hline \multicolumn{2}{|c|}{ a. Math \& computer science classes } & 2.4 & 2.3 & 2.0 & 2.4 & 2.3 \\
\hline \multicolumn{2}{|c|}{ b. Psychology, sociology, geography } & 1.9 & 2.2 & 2.0 & 2.3 & 2.3 \\
\hline \multicolumn{2}{|c|}{ c. Accounting \& finance classes } & 1.7 & 1.5 & 1.6 & 1.5 & 1.5 \\
\hline \multicolumn{7}{|c|}{ Relatively higher portion of grade based on: } \\
\hline \multicolumn{2}{|c|}{ a. Class participation. } & 1.7 & 1.7 & 1.7 & 1.8 & 1.7 \\
\hline \multicolumn{2}{|c|}{ b. Exam performance. } & 2.4 & 2.3 & 2.7 & 2.3 & 2.3 \\
\hline \multicolumn{2}{|c|}{ c. Project } & 1.4 & 1.3 & 1.1 & 1.2 & 1.3 \\
\hline \multicolumn{7}{|c|}{ Relatively more emphasis should be given to: } \\
\hline \multicolumn{2}{|c|}{ a. Starting a new firm. } & 1.5 & 1.4 & 1.3 & 1.4 & 1.5 \\
\hline \multicolumn{2}{|c|}{ b. Growing an existing firm. } & 2.1 & 2.0 & 2.4 & 2.2 & 2.2 \\
\hline \multicolumn{2}{|c|}{ c. Private Equity/LBOs/Spin-outs. } & 1.9 & 2.2 & 2.1 & 2.3 & 2.3 \\
\hline \multicolumn{2}{|c|}{ d. Venture Capital. } & 1.6 & 1.7 & 1.9 & 1.8 & 1.8 \\
\hline \multicolumn{2}{|c|}{ Highest rated pedagogy } & speakers & speakers & cases & speakers & speakers \\
\hline \multicolumn{2}{|c|}{ Next highest } & cases & project & speakers & project & project \\
\hline \multicolumn{2}{|c|}{ Then next } & project & cases & project & cases & cases \\
\hline
\end{tabular}

\section{CONCLUSION}

The general applicability of these results to other universities and teachers of entrepreneurship might be questionable. The sample is small (65). The population and the sample are from alums of a highly selective, private, 4year liberal arts college, which has no business department or entrepreneurship track/program. The opinions of former students of one entrepreneurship class taken from 1 to 20 years earlier perhaps should not be as valued as from, say, successful entrepreneurs of high growth ventures.

With those caveats in mind the clearest messages seen are the importance of using guest entrepreneur speakers in an undergraduate entrepreneurship class. There is strong support for teaching such a class to undergraduates in a liberal arts college. They also were very supportive of the use of entrepreneurial case studies in teaching such a class.

Most surprising was their thumbs down on the importance of the textbook and journal articles. Perhaps if they had been taught from one of the latest breed of entrepreneurship textbooks like the Barringer and Ireland new book (Barringer, 2006), they would see that many more stories and cases about recent entrepreneurial ventures from Google to Panera Bread are packed in than the texts they might recall. The latest textbooks might be anticipating the alumni concerns reported herein. 
These respondents preferred emphasis on start ups and new ventures to emphasis, say, on private equity and LBO's. Their thumbs down on textbooks and journal articles might not be inconsistent with their disagreement that in grading such a course emphasis should be given to performance on exams. They would emphasize much more students' achievements on a project and on class participation.

The Timmons ORT entrepreneurial process model (Timmons 2004, p. 57) summarizes perhaps the three most important factors affecting a new venture: A good Opportunity, appropriate Resources, and an excellent entrepreneurial Team. The respondents to our questionnaire were almost unanimous indicating their support that the emphasis of the course should be on those themes.

\section{REFERENCES}

1. Katts, Jerome A. 2004 Survey of Endowed Positions in Entrepreneurship and Related Fields in the United States, Price Institute for Entrepreneurial Studies, www.priceinstitute.org

2. $\quad$ Kauffman Fund, at www.Kauffman.org

3. Timmons, Jeffrey A. and Stephen Spinelli. (2004). New Venture Creation: Entrepreneurship for the $21^{\text {st }}$ Century. $6^{\text {th }}$ ed., Irwin McGraw Hill.

4. Barringer, Bruce A. and R. Duane Ireland. (2006.). Entrepreneurship: Successfully Launching New Ventures. Pearson Prentice Hall.

\section{APPENDIX}

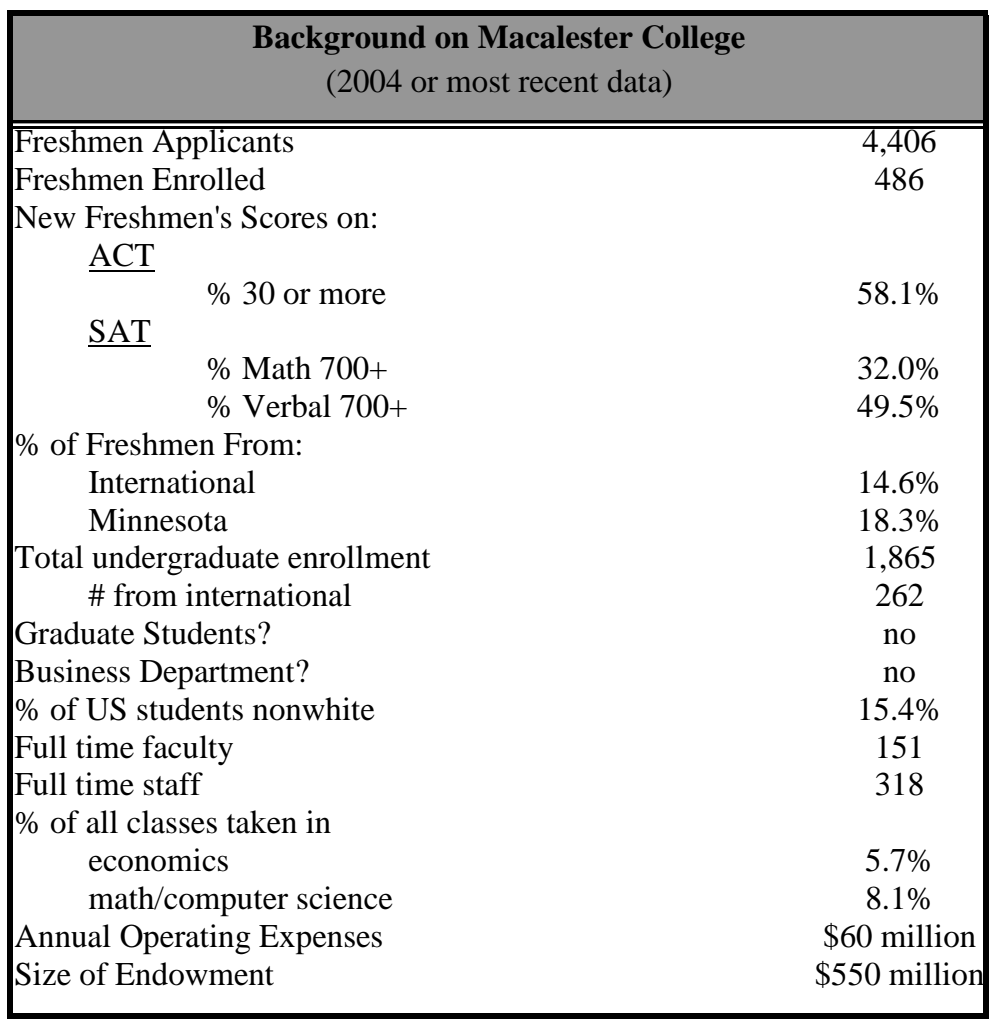




\section{NOTES}

